\title{
Assessment of Nutritional Status of Guava Seedlings using Preliminary DRIS Norms and Sufficiency Ranges
}

\author{
H. A. Souza, D. E. Rozane, D. A. Amorim, M. J. T. Dias, V. C. Modesto \& W. \\ Natale
}

To cite this article: H. A. Souza, D. E. Rozane, D. A. Amorim, M. J. T. Dias, V. C. Modesto \& W. Natale (2015) Assessment of Nutritional Status of Guava Seedlings using Preliminary DRIS Norms and Sufficiency Ranges, Journal of Plant Nutrition, 38:10, 1611-1618, DOI: 10.1080/01904167.2015.1017050

To link to this article: https://doi.org/10.1080/01904167.2015.1017050

Mar 2015.

Published online: 20 Jul 2015.

Submit your article to this journal $₫$

Џ Article views: 116

View Crossmark data ¿

Citing articles: 4 View citing articles $\longleftarrow$ 


\title{
ASSESSMENT OF NUTRITIONAL STATUS OF GUAVA SEEDLINGS USING PRELIMINARY DRIS NORMS AND SUFFICIENCY RANGES
}

\author{
H. A. Souza, ${ }^{1}$ D. E. Rozane, ${ }^{2}$ D. A. Amorim, ${ }^{3}$ M. J. T. Dias, ${ }^{4}$ V. C. Modesto, ${ }^{4}$ \\ and W. Natale ${ }^{4}$ \\ ${ }^{1}$ Brazilian Agricultural Research Corporation/CNPC, Sobral, Brazil \\ ${ }^{2}$ State University of São Paulo, Registro, Brazil \\ ${ }^{3}$ Agricultural Research Company of Minas Gerais, Uberaba, Brazil \\ ${ }^{4}$ State University of São Paulo, Jaboticabal, Brazil
}

\begin{abstract}
$\square \quad$ The objective of this work was to propose preliminary Diagnosis and Recommendation Integrated System (DRIS) norms and derive critical levels and nutrient sufficiency ranges in the leaves of guava plants in commercial nursery conditions. Sixty-eight leaf samples were evaluated from fertilization trials with seedlings. In the low-yield subpopulation ( $84 \%$ of the population), the limiting nutrients by deficiency in descending order were nitrogen $(N)>$ copper $(C u)>$ phosphorus $(P)=$ potassium $(K)>$ manganese $(M n)>$ iron $(F e)=$ zinc $(Z n)>$ sulfur $(S)>$ boron $(B)=$ magnesium $(\mathrm{Mg})>$ calcium $(\mathrm{Ca})$, and the limiting ones by excess in descending order were $B>C a>F e>M n>S>M g>C u>P>Z n>N=K$. The ranges of the appropriate DRIS indices were 24 to 28, 2.4 to 3.1, 21 to 29, 6 to 8, 1.9 to 2.9 and 1.9 to $2.3\left(\mathrm{~g} \mathrm{~kg}^{-1}\right)$ for the macronutrients $\mathrm{N}, \mathrm{P}, \mathrm{K}, \mathrm{Ca}, \mathrm{Mg}$ and $\mathrm{S}$, respectively, and 35 to 48, 4 to 15, 68 to 93, 31 to 60 and 180 to $245\left(\mathrm{mg} \mathrm{kg}^{-1}\right)$ for the micronutrients $\mathrm{B}, \mathrm{Cu}, \mathrm{Fe}, \mathrm{Mn}$ and $\mathrm{Zn}$, respectively. The dry matter production of guava seedlings was associated with the nutritional status.
\end{abstract}

Keywords: Psidium guajava, nursery, leaf analysis

\section{INTRODUCTION}

Brazil is one of the world's leading producers of guavas, with the states of São Paulo and Pernambuco leading the way. To maintain orchard productivity and longevity it is necessary to obtain healthy and well-nourished plants. This starts with the proper nourishment of seedlings in nurseries

Received 28 October 2012; accepted 11 December 2013.

Address correspondence to H. A. Souza, Brazilian Agricultural Research Corporation/CNPC, Estrada Sobral-Groaíras, km 04, s/n, Zona Rural, Sobral 62010-970, Brazil. E-mail: henrique.souza @embrapa.br 
through correct fertilization to make them more vigorous and resistant to bad weather and pests.

However, fertilization in nurseries is often done without proper technical support, due to the absence of scientific information to assist in assessment of the nutritional state in the seedling phase. Although charts that track nutrient sufficiency ranges and methods that help in assessing the most limiting nutrient, such as the Diagnosis and Recommendation Integrated System (DRIS), can contribute to the management and hence the production of good seedlings, there is still a need to establish norms or adequate concentrations for plants.

The DRIS index is nothing more than the mean of the deviations in the ratios of a determined nutrient in relation to its respective optimal values. Each ratio between nutrients in the high-yield population constitutes the DRIS norm and has its respective mean and standard deviation.

The usual methods for interpretation of chemical analysis in leaves are performed from the comparison of nutrient concentrations diagnosed with reference values such as the critical level (CL) or sufficiency ranges (SR), characterized by the independence of nutrients. Thus, the level of a nutrient does not affect the classification of others, but has the serious limitation of not identify which nutrients are most limiting (van Raij et al., 1997). The DRIS method is an alternative to the interpretation of results of leaf analysis, since the method allows the calculation of indexes for each nutrient, using its relations with others and comparing them with a population reference (Beaufils, 1973), instead of the absolute and isolated concentration from each one.

This article proposes preliminary DRIS norms and derives the critical levels and nutrient sufficiency ranges in the leaf tissue of guava seedlings, under conditions in a commercial nursery in the state of São Paulo, Brazil.

\section{MATERIALS AND METHODS}

The nutritional monitoring was carried out in the seeding production area of São João Farm, located in the municipality of Taquaritinga, SP, located at $21^{\circ} 44^{\prime} 44^{\prime \prime} \mathrm{S}$ latitude and $48^{\circ} 29^{\prime} 53^{\prime \prime} \mathrm{W}$ longitude, at an altitude of $512 \mathrm{~m}$. The climate in the region can be classified as Cwa on the Köeppen scale, described as subtropical with most rainfall occurring in the summer and relatively dry winters.

We utilized guava seedlings of the Paluma cultivar, the most commonly planted in Brazil, obtained through vegetative propagation. The mother plants were selected and pruned 70 days before removal of the herbaceous cuttings. The cuttings, composed of a stem segment with a pair of leaves, were initially maintained in a nebulization chamber with intermittent ap- 
plication of water for a period of 90 days, until rooting. Then they were transplanted from the chamber to the nursery area, which was covered with Sombrite ${ }^{\mathbb{R}}$ shade screen (rated at $30 \%$ blockage). Each seedling was planted in a polyethylene bag $(14 \times 22 \mathrm{~cm})$ with volume of $1.5 \mathrm{dm}^{3}$, containing substrate based on pine bark (Multiplant ${ }^{\mathbb{R}}$ ), placed on benches without spacing between bags. The nursery has a microsprayer system which is activated daily long enough to provide sufficient water without overwatering the plants.

We utilized the results of the experiment of Dias et al. (2012), which had a factorial design with the following doses of nitrogen $(\mathrm{N})$ and potassium (K) applied to Paluma guava seedlings: zero, 552, 828 and 1,104 $\mathrm{mg} \mathrm{dm}^{-3}$ of $\mathrm{N}$; and zero, 726, 1,089 and 1,452 $\mathrm{mg} \mathrm{dm}^{-3}$ of $\mathrm{K}$. The sources of the two nutrients were urea and potassium chloride, respectively, applied manually on the surface every 30 days, in three portions, the first one month after transplanting to the nursery. We also considered the results of another study with the Paluma guava seedlings (Natale et al., 2011), where the plants were submitted to the following doses of phosphorous $(\mathrm{P})$ applied at the moment of transplanting: zero, 50, 100, 200 and $400 \mathrm{mg} \mathrm{dm}^{-3}$ of $\mathrm{P}$. The phosphorous source was triple superphosphate.

Therefore, the analysis of the nutritional state was based on 68 leaf observations from both the experiments described above.

The leaves were collected after 120 days of growth in the nursery, when the seedlings had in general reached $50 \mathrm{~cm}$ in height. The leaves were taken from the basal, middle and top third of the seedlings, to determine the concentrations of macronutrients ( $\mathrm{N}$ - nitrogen, $\mathrm{P}$ - phosphorus, $\mathrm{K}$ potassium, $\mathrm{Ca}$ - calcium, $\mathrm{Mg}$ - magnesium and $\mathrm{S}$ - sulfur) and micronutrients (B - boron, $\mathrm{Cu}$ - copper, Fe - iron, Mn - manganese and $\mathrm{Zn}$ - zinc).

The data utilized to form the database and to develop the DRIS system were the total concentration of nutrients $\left(\mathrm{g} \mathrm{kg}^{-1}\right.$ and $\left.\mathrm{mg} \mathrm{kg}^{-1}\right)$ in the leaves as well as the total yield of dry matter of the seedlings (roots and aerial part).

To establish the DRIS norms, the database was divided into two subpopulations, one with high productivity (or the reference population) and the other with low productivity. The high-yield population was established based on the yields higher than the mean yield plus its standard deviation $(\mathrm{m}+\mathrm{s})$, which in this case was $20.06 \mathrm{~g}$.

The mean, coefficient of variation and variance were calculated for the reference group (high-yield population) and low-yield population by using the direct and inverse relations between the nutrients.

To calculate the nutrient ratio functions, we applied the physiological diagnosis method, whose formula was simplified by Jones (1981). To calculate the DRIS indices, we applied the general formula proposed by Beaufils (1973). In both cases, we used a value of $\mathrm{k}=1$.

The nutritional balance index (NBI) was calculated by summing the absolute values obtained for each nutrient. The mean nutritional balance index $\left(\mathrm{NBI}_{\mathrm{m}}\right)$ was calculated by summing the absolute values obtained for 
each nutrient and dividing the result by the total number of nutrients $(\mathrm{n})$ (Wadt et al., 1998).

The DRIS indices were interpreted after classifying the nutrients according to the potential response to fertilization (PRF) (Wadt et al., 1998). For greater synthesis, the positive potential response $(\mathrm{p})$ and positive or zero potential response (pz) classes, and also the negative $(\mathrm{n})$ and negative or zero (nz) potential response classes, were grouped and called, respectively, the limits by deficiency (LD) or limits by excess (LE). The zero response class (z) was called non-limiting (NL), according to Silva et al. (2005).

To establish the optimal level (or critical level - CL) of each nutrient, we calculated the ratio of each nutrient with its respective nutritional balance index. Therefore, the optimal leaf concentrations of $\mathrm{N}, \mathrm{P}, \mathrm{K}, \mathrm{Ca}, \mathrm{Mg}, \mathrm{S}, \mathrm{B}$, $\mathrm{Cu}, \mathrm{Fe}, \mathrm{Mn}$ and $\mathrm{Zn}$ for the Paluma guava seedlings were obtained by setting all the indexes equal to zero in a linear equation $(y=a x+b=0)$, because theoretically the optimal nutritional condition of the plant occurs when all these indices tend to zero. The analyses of the relationship between the nutrient concentration and the DRIS index were performed with the help of the SISVAR software (Ferreira, 2011). The lower and upper limits of the normal nutrient range for the DRIS were determined analogously to the method used by Urano et al. (2007), which consisted of setting the statistical models of the nutrient concentration relationships and the DRIS indices equal to zero $\pm 2 / 3$ of the standard deviation.

\section{RESULTS AND DISCUSSION}

Of the 68 samples analyzed, $11(68 \%)$ were considered high yield, or belonging to the reference subpopulation (mean + standard deviation). The remaining 57 (84\%) were considered as the low-yield subpopulation. The norms and standard deviations are presented in Table 1.

Table 2 shows the nutritional state classification. The limiting nutrients by deficiency were, in decreasing order $\mathrm{N}>\mathrm{Cu}>\mathrm{P}=\mathrm{K}>\mathrm{Mn}>\mathrm{Fe}=\mathrm{Zn}>$ $\mathrm{S}>\mathrm{Mg}=\mathrm{B}>\mathrm{Ca}$, and those limiting by excess were in decreasing order $\mathrm{B}>$ $\mathrm{Ca}>\mathrm{Fe}>\mathrm{Mn}>\mathrm{S}>\mathrm{Mg}>\mathrm{Cu}>\mathrm{P}>\mathrm{Zn}>\mathrm{N}=\mathrm{K}$.

We compared the sufficiency ranges indicated by Natale et al. (1996) for adult guava trees of the Paluma cultivar and the ranges generated in the present study against the DRIS method. Table 3 presents the sufficiency ranges. It can be seen that the amplitudes obtained by the DRIS method were different than those found in the literature. However, the ranges considered optimal by Natale et al. (1996) are merely comparative, since in that study adult plants were analyzed. Through comparison, it appears to the nutrients $\mathrm{N}, \mathrm{P}, \mathrm{K}, \mathrm{B}, \mathrm{Mn}$ and $\mathrm{Zn}$, the tracks would be overestimated and for $\mathrm{Ca}, \mathrm{Mg}, \mathrm{S}$ and $B$, tracks would be underestimated compared to that proposed by Natale et al. (1996). 
TABLE 1 Mean and standard deviation in the high-yield subpopulation

\begin{tabular}{|c|c|c|c|c|c|c|c|c|c|c|}
\hline Ratio & $\mathrm{N} / \mathrm{P}$ & $\mathrm{N} / \mathrm{K}$ & $\mathrm{N} / \mathrm{Ca}$ & $\mathrm{N} / \mathrm{Mg}$ & $\mathrm{N} / \mathrm{S}$ & $\mathrm{N} / \mathrm{B}$ & $\mathrm{N} / \mathrm{Cu}$ & $\mathrm{N} / \mathrm{Fe}$ & $\mathrm{N} / \mathrm{Mn}$ & $\mathrm{N} / \mathrm{Zn}$ \\
\hline Norm $(\mathrm{x})$ & 9.677 & 1.092 & 3.619 & 11.251 & 12.603 & 0.656 & 7.333 & 0.336 & 0.126 & 0.636 \\
\hline \multirow[t]{2}{*}{ Std. Deviation } & 2.256 & 0.367 & 0.698 & 2.537 & 1.532 & 0.171 & 8.205 & 0.085 & 0.027 & 0.179 \\
\hline & $\mathrm{P} / \mathrm{N}$ & $\mathrm{P} / \mathrm{K}$ & $\mathrm{P} / \mathrm{Ca}$ & $\mathrm{P} / \mathrm{Mg}$ & $\mathrm{P} / \mathrm{S}$ & $\mathrm{P} / \mathrm{B}$ & $\mathrm{P} / \mathrm{Cu}$ & $\mathrm{P} / \mathrm{Fe}$ & $\mathrm{P} / \mathrm{Mn}$ & $\mathrm{P} / \mathrm{Zn}$ \\
\hline Norm (x) & 0.109 & 0.120 & 0.386 & 1.190 & 1.356 & 0.069 & 0.851 & 0.036 & 0.014 & 0.071 \\
\hline \multirow[t]{2}{*}{ Std. Deviation } & 0.026 & 0.060 & 0.095 & 0.295 & 0.300 & 0.016 & 1.023 & 0.010 & 0.006 & 0.031 \\
\hline & $\mathrm{K} / \mathrm{N}$ & $\mathrm{K} / \mathrm{P}$ & $\mathrm{K} / \mathrm{Ca}$ & $\mathrm{K} / \mathrm{Mg}$ & $\mathrm{K} / \mathrm{S}$ & $\mathrm{K} / \mathrm{B}$ & $\mathrm{K} / \mathrm{Cu}$ & $\mathrm{K} / \mathrm{Fe}$ & $\mathrm{K} / \mathrm{Mn}$ & $\mathrm{K} / \mathrm{Zn}$ \\
\hline Norm (x) & 0.977 & 9.456 & 3.585 & 11.221 & 12.218 & 0.647 & 6.403 & 0.329 & 0.122 & 0.602 \\
\hline \multirow[t]{2}{*}{ Std. Deviation } & 0.209 & 2.724 & 0.975 & 3.295 & 2.735 & 0.208 & 7.214 & 0.108 & 0.037 & 0.163 \\
\hline & $\mathrm{Ca} / \mathrm{N}$ & $\mathrm{Ca} / \mathrm{P}$ & $\mathrm{Ca} / \mathrm{K}$ & $\mathrm{Ca} / \mathrm{Mg}$ & $\mathrm{Ca} / \mathrm{S}$ & $\mathrm{Ca} / \mathrm{B}$ & $\mathrm{Ca} / \mathrm{Cu}$ & $\mathrm{Ca} / \mathrm{Fe}$ & $\mathrm{Ca} / \mathrm{Mn}$ & $\mathrm{Ca} / \mathrm{Zn}$ \\
\hline Norm (x) & 0.289 & 2.728 & 0.334 & 3.094 & 3.658 & 0.181 & 2.542 & 0.093 & 0.037 & 0.190 \\
\hline \multirow[t]{2}{*}{ Std. Deviation } & 0.074 & 0.622 & 0.238 & 0.349 & 1.151 & 0.031 & 3.568 & 0.019 & 0.015 & 0.102 \\
\hline & $\mathrm{Mg} / \mathrm{N}$ & $\mathrm{Mg} / \mathrm{P}$ & $\mathrm{Mg} / \mathrm{K}$ & $\mathrm{Mg} / \mathrm{Ca}$ & $\mathrm{Mg} / \mathrm{S}$ & $\mathrm{Mg} / \mathrm{B}$ & $\mathrm{Mg} / \mathrm{Cu}$ & $\mathrm{Mg} / \mathrm{Fe}$ & $\mathrm{Mg} / \mathrm{Mn}$ & $\mathrm{Mg} / \mathrm{Zn}$ \\
\hline Norm (x) & 0.096 & 0.893 & 0.115 & 0.327 & 1.213 & 0.059 & 0.899 & 0.031 & 0.012 & 0.064 \\
\hline \multirow[t]{2}{*}{ Std. Deviation } & 0.036 & 0.244 & 0.104 & 0.041 & 0.520 & 0.011 & 1.390 & 0.009 & 0.007 & 0.044 \\
\hline & $\mathrm{S} / \mathrm{N}$ & $\mathrm{S} / \mathrm{P}$ & $\mathrm{S} / \mathrm{K}$ & $\mathrm{S} / \mathrm{Ca}$ & $\mathrm{S} / \mathrm{Mg}$ & $\mathrm{S} / \mathrm{B}$ & $\mathrm{S} / \mathrm{Cu}$ & $\mathrm{S} / \mathrm{Fe}$ & $\mathrm{S} / \mathrm{Mn}$ & $\mathrm{S} / \mathrm{Zn}$ \\
\hline Norm $(x)$ & 0.080 & 0.769 & 0.087 & 0.291 & 0.903 & 0.053 & 0.554 & 0.027 & 0.010 & 0.051 \\
\hline \multirow[t]{2}{*}{ Std. Deviation } & 0.009 & 0.160 & 0.026 & 0.066 & 0.206 & 0.015 & 0.575 & 0.008 & 0.003 & 0.015 \\
\hline & $\mathrm{B} / \mathrm{N}$ & $\mathrm{B} / \mathrm{P}$ & $\mathrm{B} / \mathrm{K}$ & $\mathrm{B} / \mathrm{Ca}$ & $\mathrm{B} / \mathrm{Mg}$ & $\mathrm{B} / \mathrm{S}$ & $\mathrm{B} / \mathrm{Cu}$ & $\mathrm{B} / \mathrm{Fe}$ & $\mathrm{B} / \mathrm{Mn}$ & $\mathrm{B} / \mathrm{Zn}$ \\
\hline Norm (x) & 1.640 & 15.243 & 1.868 & 5.693 & 17.554 & 20.803 & 15.306 & 0.521 & 0.211 & 1.075 \\
\hline \multirow[t]{2}{*}{ Std. Deviation } & 0.499 & 3.445 & 1.222 & 1.143 & 3.780 & 7.493 & 20.683 & 0.097 & 0.091 & 0.557 \\
\hline & $\mathrm{Cu} / \mathrm{N}$ & $\mathrm{Cu} / \mathrm{P}$ & $\mathrm{Cu} / \mathrm{K}$ & $\mathrm{Cu} / \mathrm{Ca}$ & $\mathrm{Cu} / \mathrm{Mg}$ & $\mathrm{Cu} / \mathrm{S}$ & $\mathrm{Cu} / \mathrm{B}$ & $\mathrm{Cu} / \mathrm{Fe}$ & $\mathrm{Cu} / \mathrm{Mn}$ & $\mathrm{Cu} / \mathrm{Zn}$ \\
\hline Norm (x) & 0.348 & 3.452 & 0.333 & 1.318 & 4.183 & 4.246 & 0.254 & 0.129 & 0.044 & 0.210 \\
\hline \multirow[t]{2}{*}{ Std. Deviation } & 0.297 & 3.092 & 0.246 & 1.116 & 3.658 & 3.587 & 0.229 & 0.118 & 0.038 & 0.186 \\
\hline & $\mathrm{Fe} / \mathrm{N}$ & $\mathrm{Fe} / \mathrm{P}$ & $\mathrm{Fe} / \mathrm{K}$ & $\mathrm{Fe} / \mathrm{Ca}$ & $\mathrm{Fe} / \mathrm{Mg}$ & $\mathrm{Fe} / \mathrm{S}$ & $\mathrm{Fe} / \mathrm{B}$ & $\mathrm{Fe} / \mathrm{Cu}$ & $\mathrm{Fe} / \mathrm{Mn}$ & $\mathrm{Fe} / \mathrm{Zn}$ \\
\hline Norm $(x)$ & 3.196 & 30.386 & 3.515 & 11.168 & 34.846 & 40.807 & 1.982 & 29.286 & 0.402 & 2.009 \\
\hline \multirow[t]{2}{*}{ Std. Deviation } & 0.991 & 10.533 & 1.727 & 2.609 & 9.912 & 16.327 & 0.382 & 40.751 & 0.140 & 0.821 \\
\hline & $\mathrm{Mn} / \mathrm{N}$ & $\mathrm{Mn} / \mathrm{P}$ & $\mathrm{Mn} / \mathrm{K}$ & $\mathrm{Mn} / \mathrm{Ca}$ & $\mathrm{Mn} / \mathrm{Mg}$ & $\mathrm{Mn} / \mathrm{S}$ & $\mathrm{Mn} / \mathrm{B}$ & $\mathrm{Mn} / \mathrm{Cu}$ & $\mathrm{Mn} / \mathrm{Fe}$ & $\mathrm{Mn} / \mathrm{Zn}$ \\
\hline Norm (x) & 8.213 & 81.573 & 8.823 & 29.977 & 93.832 & 103.802 & 5.484 & 58.270 & 2.759 & 5.091 \\
\hline \multirow[t]{2}{*}{ Std. Deviation } & 1.483 & 29.433 & 2.487 & 8.325 & 30.056 & 24.125 & 2.014 & 63.594 & 0.873 & 1.366 \\
\hline & $\mathrm{Zn} / \mathrm{N}$ & $\mathrm{Zn} / \mathrm{P}$ & $\mathrm{Zn} / \mathrm{K}$ & $\mathrm{Zn} / \mathrm{Ca}$ & $\mathrm{Zn} / \mathrm{Mg}$ & $\mathrm{Zn} / \mathrm{S}$ & $\mathrm{Zn} / \mathrm{B}$ & $\mathrm{Zn} / \mathrm{Cu}$ & $\mathrm{Zn} / \mathrm{Fe}$ & $\mathrm{Zn} / \mathrm{Mn}$ \\
\hline Norm (x) & 1.774 & 17.464 & 1.846 & 6.464 & 20.406 & 22.211 & 1.186 & 11.437 & 0.577 & 0.215 \\
\hline Std. Deviation & 0.886 & 10.118 & 0.806 & 3.259 & 11.459 & 10.521 & 0.690 & 11.893 & 0.237 & 0.083 \\
\hline
\end{tabular}


TABLE 2 Frequency (\%) of diagnosis for evaluation of the nutritional state by the DRIS method, in leaf samples collected in a commercial guava nursery, in the low-yield subpopulation ${ }^{(1)}$

\begin{tabular}{lrrr}
\hline Nutrient & LD $^{(2)}$ & $\begin{array}{l}\text { NL } \\
\%\end{array}$ & LE \\
\hline $\mathrm{N}$ & & 59.6 & 1.8 \\
$\mathrm{P}$ & 38.6 & 64.9 & 10.5 \\
$\mathrm{~K}$ & 24.6 & 73.7 & 1.8 \\
$\mathrm{Ca}$ & 24.6 & 56.1 & 38.6 \\
$\mathrm{Mg}$ & 5.3 & 73.7 & 15.8 \\
$\mathrm{~S}$ & 10.5 & 68.4 & 19.3 \\
$\mathrm{~B}$ & 12.3 & 31.6 & 57.9 \\
$\mathrm{Cu}$ & 10.5 & 50.9 & 12.3 \\
$\mathrm{Fe}$ & 36.8 & 57.9 & 28.1 \\
$\mathrm{Mn}$ & 14.0 & 61.4 & 21.1 \\
$\mathrm{Zn}$ & 17.5 & 78.9 & 7.0 \\
\hline
\end{tabular}

${ }^{(1)}$ Lower than the mean + standard deviation.

${ }^{(2)} \mathrm{LD}$ - limiting by deficiency; NL - non-limiting; LE - limiting by excess.

TABLE 3 Normal nutrient range in leaf samples collected in a commercial guava nursery obtained by the DRIS method and method from the literature used for comparison of the values ${ }^{(1)}$

\begin{tabular}{lccc}
\hline Nutrient & Method & Optimal range & Optimal content \\
\hline $\mathrm{N}$ & DRIS $^{(2)}$ & $24-28$ & 26 \\
$\mathrm{P}$ & Literature & $20-23$ & - \\
& DRIS & $2.4-3.1$ & 2.8 \\
$\mathrm{~K}$ & Literature & $1.4-1.8$ & - \\
& DRIS & $21-29$ & 25 \\
$\mathrm{Ca}$ & Literature & $14-17$ & - \\
& DRIS & $6-8$ & 7 \\
$\mathrm{Mg}$ & Literature & $7-11$ & - \\
& DRIS & $1.9-2.9$ & 2.4 \\
$\mathrm{~S}$ & Literature & $3.4-4.0$ & - \\
& DRIS & $1.9-2.3$ & 2.1 \\
$\mathrm{~B}$ & Literature & $2.5-3.5$ & - \\
& DRIS & $35-48$ & 41 \\
$\mathrm{Cu}$ & Literature & $20-25$ & - \\
& DRIS & $4-15$ & 9 \\
$\mathrm{Fe}$ & Literature & $20-40$ & - \\
& DRIS & $68-93$ & 81 \\
$\mathrm{Mn}$ & Literature & $60-90$ & - \\
$\mathrm{Zn}$ & DRIS & $180-245$ & 213 \\
& Literature & $40-80$ & - \\
& DRIS & $31-60$ & 46 \\
& Literature & $25-35$ & - \\
& & &
\end{tabular}

\footnotetext{
${ }^{(1)}$ Natale et al. (1996).

${ }^{(2)}$ Optimal range estimated from the lower and upper limits by setting the nutrient concentration equations and DRIS indices equal to zero $\pm 2 / 3$ of the standard deviation, according to Urano et al. (2007).
} 


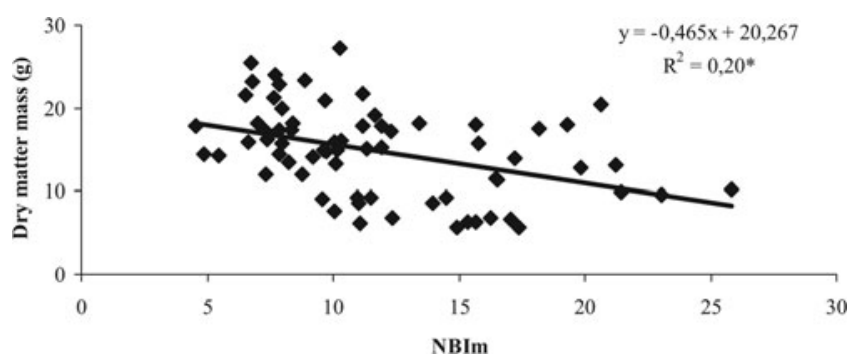

FIGURE 1 Ratio between the $\mathrm{NBI}_{\mathrm{m}}$ values and the dry matter mass in guava seedlings.

The contents of the moving leaf decrease with age, while the properties of the elements increase, therefore the relationship between a mobile and an immobile nutrient could not remain constant over time. This fact contradicts one of the premises for the DRIS at any sampling time (Reis and Monnerat, 2002). Thus, it is reasonable to assume that the universality attributed to DRIS norms may be responsible for failure diagnosis found with this methodology (Reis and Monnerat, 2002).

Figure 1 shows the dispersion of the ratios between the $\mathrm{NBI}_{\mathrm{m}}$ and productivity values of the seedlings (dry matter mass). Although significant, the value of the coefficient of determination was low. According to Bataglia et al. (2004), improvements in nutritional diagnosis can be obtained by attributing different sensitivity levels to nutrients that have greater or lesser effect on productivity.

The regression between NBIm and productivity (Figure 1) revealed that the production of dry matter was significantly associated with nutritional status of plants $(\mathrm{p}<0.05)$.

Employing the DRIS method, Bataglia et al. (2008) established nutrient concentration ranges in citrus tree leaves for various grafts and seedlings cultivated in protected conditions in a commercial substrate. According to the authors, the advantage of using ratios from the DRIS method is that they are less subject to variations due to plant age and the effects of concentration or dilution relative to phytomass production.

\section{CONCLUSIONS}

- The limiting nutrients by deficiency in descending order were $\mathrm{N}>\mathrm{Cu}>$ $\mathrm{P}=\mathrm{K}>\mathrm{Mn}>\mathrm{Fe}=\mathrm{Zn}>\mathrm{S}>\mathrm{B}=\mathrm{Mg}>\mathrm{Ca}$, and the limiting ones by excess in descending order were $\mathrm{B}>\mathrm{Ca}>\mathrm{Fe}>\mathrm{Mn}>\mathrm{S}>\mathrm{Mg}>\mathrm{Cu}>\mathrm{P}$ $>\mathrm{Zn}>\mathrm{N}=\mathrm{K}$.

- The ranges of the appropriate DRIS indices were 24 to $28,2.4$ to $3.1,21$ to 29,6 to $8,1.9$ to 2.9 and 1.9 to $2.3\left(\mathrm{~g} \mathrm{~kg}^{-1}\right)$ for the macronutrients $\mathrm{N}$, $\mathrm{P}, \mathrm{K}, \mathrm{Ca}, \mathrm{Mg}$ and $\mathrm{S}$, respectively, and 35 to 48,4 to 15,68 to 93,31 to 60 
and 180 to $245\left(\mathrm{mg} \mathrm{kg}^{-1}\right)$ for the micronutrients $\mathrm{B}, \mathrm{Cu}, \mathrm{Fe}, \mathrm{Mn}$ and $\mathrm{Zn}$, respectively.

- The dry matter production of guava seedlings was associated with the nutritional status.

\section{REFERENCES}

Bataglia, O. C., P. R. Furlani, R. S. Ferrarezi, and C. L. Medina. 2008. Nutritional support of citrus seedlings. Araraquara, Brazil: Vivecitrus/Conplant.

Bataglia, O. C., J. A. Quaggio, W. R. Santos, and M. F. Abreu. 2004. Nutrient diagnosis of coffee-tree by DRIS using different sensitive constants according to the nutrient yield response. Bragantia 63 : 253-263.

Beaufils, E. R. 1973. Diagnosis and recommendation integrated system (DRIS). Pietermararitzburg, South Africa: University of Natal.

Dias, M. J. T., H. A. Souza, W. Natale, V. C. Modesto, and D. E. Rozane. 2012. Fertilization with nitrogen and potassium in guava seedlings in a commercial nursery. Semina: Ciências Agrárias 33: 2837-2848.

Ferreira, D. F. 2011. Sisvar: A computer statistical analysis system. Ciência e Agrotecnologia 35: 1039-1042.

Jones, C. A. 1981. Proposed modifications of the diagnosis and recommendation integrated system (DRIS) for interpreting plant analyses. Communications in Soil Science and Plant Analysis 12: 785-794.

Natale, W., E. L. M. Coutinho, A. E. Boaretto, and F. M. Pereira. 1996. Guava Tree: Liming and Fertilizer. Jaboticabal, Brazil: FUNEP.

Natale, W., H. A. Souza, M. J. T. Dias, V. C. Modesto, and D. E. Rozane. 2011. Phosphurus fertilization on seedlings in the nursery trade of guava tree. Abstract presented at Brazilian Congress of Soil Science. Uberlândia, Brazil: Brazilian Congress of Soil Science.

Reis, R. A., Jr., and P. H. Monnerat. 2002. Sugarcane nutritional diagnosis with DRIS norms established in Brazil, South Africa, and the United States. Journal of Plant Nutrition 25: 831-851.

Silva, G. G. C., J. C. L. Neves, and V. V. H. Alvarez. 2005. Evaluation of the universality of DRIS, M-DRIS, and CND norms. Revista Brasileira de Ciência do Solo 29: 755-761.

Urano, E. O., C. H. Kurihara, S. Maeda, A. C. T. Vitorino, M. C. Gonçalves, and A. E. Marchetti. 2007. Determination of optimal nutrient contents for soybean by the mathematical chance, diagnosis and recommendation integrated system and compositional nutrient diagnosis methods. Revista Brasileira de Ciência do Solo 31: 63-72.

van Raij, B., H. Cantarella, J. A. Quaggio, and A. M. C. Furlani. 1997. Recommendations of Fertilization and Liming for the State of São Paulo. Campinas, Brazil: Agronômica Institute.

Wadt, P. G. S., R. F. Novais, V. V. H. Alvarez, S. Fonseca, N. F. Barros, and L. E. Dias. 1998. Nutrient potential response of eucalypt plantations as evaluated by three methods of estimating DRIS indices. Revista Brasileira de Ciência do Solo 22: 661-666. 